Original Research Paper

\title{
Program RPL sebagai Upaya Memenuhi Kebutuhan Sayuran pada Masa Pandemi Covid-19 di Area Perumahan dengan Luas Pekarangan Terbatas
} \author{
Nurtadahlia $^{4}$ \\ ${ }^{I}$ Program Studi Teknik Sipil, FakultasTeknik, Universitas Mataram, Indonesia \\ ${ }^{2}$ Program Studi Budidaya Perairan, Fakultas Pertanian, Universitas Mataram, Indonesia \\ ${ }^{3}$ Program Studi Kehutanan, Fakultas Pertanian, Universitas Mataram, Indonesia \\ ${ }^{4}$ Program Studi Pertenakan, Fakultas Pertenakan, Universitas Mataram, Indonesia
}

I Dewa Made Alit Karyawan ${ }^{*}$, Rahmat Wahyudi², Bagus Ansani Takwin², Iwan Kurniawan², Yusmihad Hamzani $^{2}$, Handika Restu Fauzi $^{2}$, Supiandi ${ }^{2}$, Desi Melanisia ${ }^{2}$, Sulastri ${ }^{3}$, Nita Nurwahdania ${ }^{3}$, Siti

https://doi.org/10.29303/jpmpi.v3i2.928

Sitasi: Karyawan, I. D. M. A., Wahyudi, R., Takwin, B. A., Kurniawan, I., Hamzani, Y., Fauzi, H. R., Supiandi., Melanisia, D., Sulastri., Nurwahdania, N., \& Nurtadahlia, S. (2021). Program RPL sebagai Upaya Memenuhi Kebutuhan Sayuran pada Masa Pandemi Covid-19 di Area Perumahan dengan Luas Pekarangan Terbatas. Jurnal Pengabdian Magister Pendidikan IPA, 4(3)

\section{Article history}

Received: 22 Juli 2021

Revised: 31 Juli 2020

Accepted: 30 Agustus 2021

*Corresponding Author: I Dewa Made Alit Karyawan, Program Studi Teknik Sipil, Universitas Mataram, Mataram, Indonesia;

Email: dewaalit@unram.ac.id

\begin{abstract}
Selama pandemi Covid-19, aktivitas di luar rumah dibatasi. Namun pembatasan ini tidak boleh menghentikan produktivitas masyarakat dalam memenuhi kebutuhan pangannya. Terkait hal tersebut, mahasiswa KKN-Unram menawarkan solusi kepada masyarakat dengan memanfaatkan waktu di rumah. Program yang ditawarkan adalah Rumah Pangan Lestari (RPL) yaitu berkebun sayur di pekarangan rumah dengan menggunakan botol bekas, styrofoam, gelas plastik dan alat sederhana. Tujuannya untuk mengedukasi masyarakat agar dapat memanfaatkan ruang kosong di pekarangan rumah untuk dijadikan tempat bercocok tanam sayuran, dengan menggunakan sistem hidroponik. Program ini dilaksanakan dalam dua kegiatan yaitu pembuatan kebun contoh dan sosialisasi kebun sayur pada lahan terbatas. Metode berkebun yang diterapkan adalah metode hidroponik yang ditempatkan di dalam screen house dan dengan media tanah. Kebun contoh digunakan sebagai tempat pelaksanaan materi sosialisasi kepada masyarakat. Sosialisasi menekankan bagaimana menanam sayuran di pekarangan sempit dengan menggunakan botol bekas dan kemasan berbahan styrofoam. Program sesuai rencana, karena keseriusan mahasiswa dan dukungan masyarakat. Mereka tertarik dengan program yang ditawarkan mahasiswa KKN karena menggunakan alat dan bahan yang mudah didapat. Masyarakat sangat antusias datang dan berdiskusi dalam kegiatan sosialisasi dan pelatihan di taman percontohan. Sayuran di kebun percontohan sudah bisa dipanen setelah 40 hari dan hasilnya dibagikan kepada masyarakat sekitar lokasi pelaksanaan program.
\end{abstract}

Keywords: hidroponik, kebun di pekarangan, sayuran, screen house.

\section{Pendahuluan}

Pandemi Covid-19 dapat menimbulkan ancaman krisis pangan, sebab para pekerja dianjurkan untuk bekerja di rumah (work from home), siswa dan mahasiswa dianjurkan belajar di rumah (study from home). Disamping adanya efek menurunnya perekonomian masyarakat (Hadiwardoyo, 2020). Karena itu, perlu digali gagasan produktif bagaimana cara memanfaatkan sumber daya dalam keterbatasan. Dalam keterbatasan dalam berkegiatan di luar rumah, 
banyak kegiatan yang dapat dilakukan di lingkungan tempat tinggal termasuk dalam upaya memenuhi kebutuhan akan pangan. Menanam sayuran adalah salah satu kegiatan yang dapat dilakukan. Melalui program Kuliah Kerja Nyata (KKN) era new norma, civitas akademika Universitas Mataram, membantu merealisasikan gagasan tersebut. Program ini merupakan salah satu bentuk pengabdian kepada masyarakat yang dilakukan secara interdisipliner, institusional, dan kemitraan sebagai salah satu bentu tridharma perguruan tinggi. KKN era new normal merupakan program KKN dengan fokus pada transformasi perilaku hidup di masyarakat dalam pandemi Covid-19 untuk tetap menjalankan aktivitas normal namun dengan menerapkan protokol kesehatan (LPPM-Unram, 2020).

Implementasi program dengan tema Rumah Pangan Lestari (RPL), yang bertujuan mengedukasi masyarakat agar dapat memanfaatkan ruang kosong di pekarangan rumah untuk dijadikan tempat bercocok tanam sayuran, dengan menggunakan sistem hidroponik. Sasarannya adalah masyarakat dil lokasi kegiatan KKN, yaitu Kelurahan Taman Sari, Kecamatan Ampenan, Kota Mataram. Masyarakat diedukasi untuk memanfaatkan pekarangan secara intensif sebagai penyedia bahan pangan rumah tangga yang berkualitas dan beragam. Meskipun lingkup implementasi masih terbatas, namun secara bertahap RPL ini diharapkan dapat dikembangkan dalam skala luas, berbasis dusun (kampung), desa, atau wilayah lain yang memungkinkan menjadi Kawasan Rumah Pangan Lestari (KRPL). Prinsip dasar KRPL adalah: (i) pemanfaatan pekarangan yang ramah lingkungan dan dirancang untuk ketahanan dan kemandirian pangan, (ii) diversifikasi pangan berbasis sumber daya lokal, (iii) konservasi sumberdaya genetik pangan (tanaman, ternak, ikan), dan (iv) menjaga kelestariannya melalui kebun bibit desa (v) peningkatan pendapatan dan kesejahteraan masyarakat (Balitbang Pertanian, 2019).

Lokasi penerapan program termasuk kawasan perkotaan, dimana Mataram adalah Ibu
Kota Provinsi NTB. Ciri kawasan perkotaan adalah sebagai tempat kegiatan industri dengan pertumbuhan penduduk yang sangat cepat sehingga banyak lahan pertanian produktif berubah fungsi menjadi pemukiman. Kondisi ini menyebabkan lahan pertanian semakin berkurang, yang berdampak langsung terhadap ketersediaan pangan. Mataram merupakan salah satu daerah perkotaan yang memiliki lahan pertanian yang sangat minim. Kepala Dinas Pertanian Kota Mataram menyatakan bahwa pada tahun 2019 Dinas Pertanian mencatat alih fungsi lahan sebanyak 48 hektare yang didominasi untuk pembangunan perumahan (Suara NTB, 2020). Pada lokasi KKN, yaitu Kelurahan Taman Sari, lahan pertanian yang berupa persawahan hanya $10,97 \mathrm{Ha}$, dari 160,708 Ha luas toal wilayah kelurahan (PPID Kota Mataram, 2020).

Ide pengembangan pertanian dengan memanfaatkan lahan sempit dapat membantu mencukupi kebutuhan pangan, terlebih ditengah pandemi ini. Metode berkebun yang cocok diterapkan adalah metode hidroponik yang ditempatkan di dalam screen house dan dengan media tanah. Sistim hidroponik dibuat dengan memanfaatkan lahan kosong atau pekarangan rumah, serta menggunakan bahan yang berupa limbah plastic atau sterofoam. Sedangkan untuk penanaman dengan media tanah dapat dilakukan dengan menggunakan wadah polybag. Hidroponik sesuai untuk lahan sempit, karena metode dalam budidaya menanamnya menekankan pada pemenuhan kebutuhan hara nutrisi bagi tanaman dengan memanfaatkan air, tanpa menggunakan media tanah. Sehingga, penerapan hidroponik memiliki beberapa kelebihan seperti: penggunaan lahan lebih efisien, kuantitas produksi lebih banyak dengan kualitas lebih baik serta lebih mudah dalam pengendalian hama dan penyakit (Distan Sukabumi, 2015). Sehingga kedua metode tersebut sesuai diterapkan dalam program Rumah Pangan Lestari KKN era new normal di Kelurahan Taman Sari, Kecamatan Ampenan, Kota Mataram. 


\section{Metode}

Metode dalam pengabdian ini terdiri dari beberapa tahapan kegiatan, dimulai dari persiapan, pelaksanaan dan pendampingan. Tahapan persiapan ini bertujuan untuk mengumpulkan informasi dalam rangka penyusunan program kerja. Dilakukan identifikasi permasalahan yang dihadapi masyarakat pada masa pandemi terutama dari kesediaan pangan untuk rumah tangga. Kegiatan dilakukan melalui wawancara dengan masyarakat (mitra), kunjungan ke kantor lurah, dan melalui studi literatur. Wawancara dilakukan dengan tujuan menggali potensi yang dapat dikembangkan dan mampu direalisasi selama pelaksanaan program. Pada kesempatan wawancara juga disampaikan gagasan-gagasan terkait dengan program RPL. Pertimbangan dalam melaksanakan program RPL yang dilihat berdasarkan kebiasaan masyarakat, demografi, tingkat kesetersediaan lahan, pendapatan warga, pekerjaan serta ketertarikan pada bidang pertanian atau perkebunan. Hasil wawancara dengan masyarakat disinkronkan melalui diskusi dengan pihak pemerintah kelurahan sehingga dapat saling mendukung pelaksanaan program. Data penunjang yang dikumpulkan berupa informasi tertulis atau dalam bentuk dokumentasi foto dan video yang berhubungan dengan tahap pelaksanaan kegiatan. Studi kepustakaan/ literatur diperlukan sebagai bahan dalam menyusun, melaksanakan dan evaluasi semua program yang ada sesuai dengan program kerja yang akan dilaksanakan dengan bimbingan dosen pembimbing lapangan (DPL).

Tahap pelaksanaan diawali dengan pembekalan kelompok KKN era new normal, tentang cara memotivasi masyarakat memanfaatkan pekarangan rumah untuk membantu mencukupi bahan pangan dimasa pandemi Covid-19. Selanjutnya dilakukan sosialisasi program kerja kepada masyarakat, untuk dilaksanakan bersama-sama. Pada kesempatan ini juga diberikan penjelasan dan mengajak masyarakat memanfaatkan lahan yang dimiliki sehingga dapat membantu penyediaan pangan rumah tangga. Memberikan penjelasan sistem hidroponik menggunakan media botol bekas yang sesuai diterapkan meskipun dipekarangan yang sempit. Sosialisasi dilakukan kepada warga, khususnya Kelompok Tani Seruni Hijau dengan melibatkan perangkat kelurahan, penyuluh, tokoh masyarakat, untuk menyampaikan maksud dan tujuan pengembangan RPL. Dilakukan juga penyebaran leaflet tentang budidaya tanaman dengan sistem hidroponik. Selanjutnya adalah pembuatan kebun percontohan, yang akan berfungsi sebagai tempat pelatihan dan pendampingan kepada mitra. Diawali dengan penyiapan lahan, pembuatan screen house tempat instalasi system hidroponik dan media tanam. Bersamaan dengan penyiapan tempat dan media tanam, dilakukan pembibitan sehingga setelah media siap maka bibit langsung dapat ditanam. Kegiatan selanjutnya adalah perawatan tanaman.

Pada saat pelaksanaan program dilakukan pendampingan dengan pendekatan learning by doing (belajar sambil bekerja/ berusaha). Selama pendampingan kepada mitra diberikan petunjuk dan contoh mulai dari cara membuat instalasi hidroponik dan media tanam, pembibitan, perawatan dan memanen hasilnya. Dilakukan juga penyuluhan secara formal yang bertujuan meningkatkan pemahaman serta kesadaran masyarakat untuk memanfaatkan pekarangan sehingga dapat membantu memenuhi kebutuhan pangan khususunya sayuran.

Selama pelaksanaan program dilakukan dokumendasi data secara tertulis dan dalam bentuk foto atau video. Informasi kegiatan juga dipublikasikan melalui media sosial. Kegiatan harian didokumentasikan dalam bentuk narasi disertai foto. Kemudian dilakukan analisis, dengan konsep (Rijali, 2018) : (1) Data collection, yaitu mengumpulkan dari hasil pengamatan, wawancara dan dokumentasi untuk bahan kajian pelaksanakan kegiatan KKN; (b) Data reduction, adalah merangkum dan memilih hal-hal pokok dan penting, sehingga dapat memberikan gambaran lebih jelas dan rinci tentang pelaksanaan kegiatan; (c) Data display, yaitu melakukan penyajian data; (d) Verification, ialah memberikan kesimpulan tentang bagaimana hasil yang akan dicapai dalam melaksanakan program rumah pangan lestari di Kelurahan Taman Sari. 


\section{Hasil dan Pembahasan}

\section{Pembuatan program kerja dan sosialisasi}

Program kerja yang dilakukan di

Kelurahan Taman Sari, Kecamatan Ampenan, Kota Mataram, Nusa Tenggara Barat adalah Rumah Pangan Lestari. Hal ini diputuskan berdasarkan identifikasi hasil pengumpulan data pada tahap persiapan program serta masukkan dari lurah dan perangkatnya. Hal ini didukung oleh kondisi masyarakat yang tinggal di kawasan permukiman padat penduduk dengan pekarangan terbatas. Telah ada kelompok tani yang bernama Seruni Hijau, dibentuk oleh ibuibu PKK (anggota arisan) yang mempunyai waktu luang untuk berkebun pada lahan yang dikelola Kelurahan Taman Sari.

Kegiatan observasi dan diskusi kepada pemerintah kelurahan dan masyarakat kelompok tani untuk mengetahui keadaan lingkungan dan potensi yang dapat dikembangkan. Diskusi dilakukan untuk mengetahui keinginan terbesar masyarakat lingkungan, tentang konsep bercocok tanam yang ditawarkan. Disepakati untuk menggunakan hidroponik. Hal ini sesuai, karena sistem ini dilakukan karena merupakan cara yang tepat untuk mmanfaatkan pekarangan rumah dilahan sempit dan terbatas (Mulasari, 2018). Disamping itu juga dilakukan penanaman dengan media tanah untuk tanaman yang tidak sesuai pada system hidroponik.

Setelah program kerja terbentuk, dilakukan sosialisasi pembuatan hidroponik, dengan sasaran masyarakat terutama kelompok Tani Seruni Hijau. Anggota kelompok tani sebagian besar ibu-ibu kelompok arisan lingkungan Seruni, Kelurahan Taman Sari. Materi sosialisasi menekankan cara menanam sayuran di pekarangan sempit dengan menggunakan botol bekas dan kemasan styrofoam. Peserta sosialisasi sangat antusias dalam mengikuti penjelasan dari tim pengabdian masyarakat. Banyak pertanyaan yang diajukan oleh peserta yang hadir, karena ketertarikannya pada hidroponik. Hal ini disebabkan hidroponik yang dikembangkan menggunakan peralatan yang sederhanan dan bahan yang sangat mudah didapatkan. Lokasi sosialisasi dilakukan di kebun contoh, sehingga pada saat sosialisasi dapat dilakukan praktek langsung dengan peralatan dan bahan yang telah disiapkan. Gambar 1 menunjukkan kegiatan sosialisasi dan edukasi.

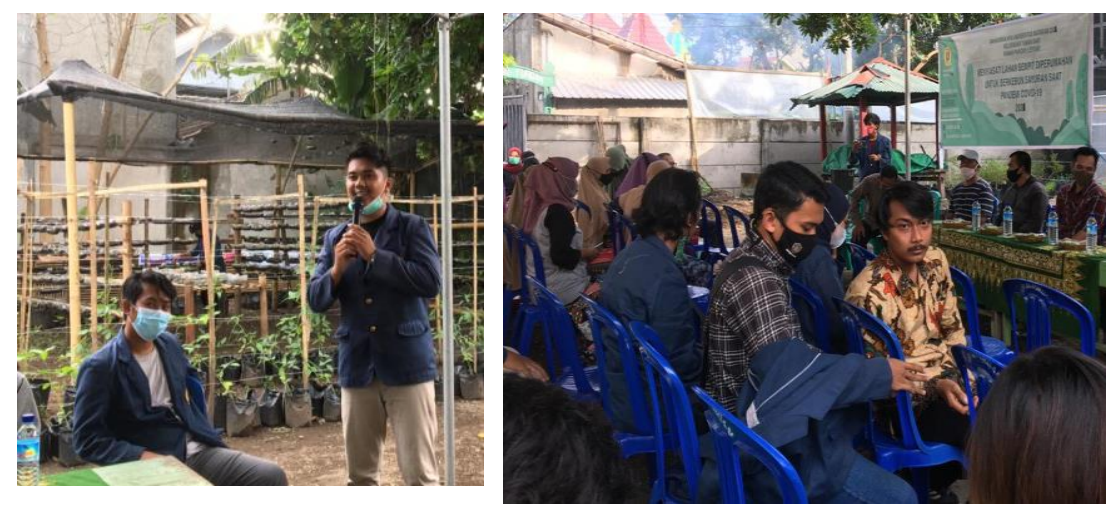

Gambar 1. Pelaksanaan sosialisai program RPL

(Sumber: Dokumentasi, 2021)

\section{Pembuatan screen house}

Pembuatan kebun contoh dilakukan pada sebidang lahan yang dikelola oleh pihak kelurahan Taman Sari. Sebagai pengaman instalasi hidroponik, dibuatkan screen house. Screen house dibuat berukuran $16 \mathrm{~m}^{2}$ dengan bahan yang murah dan mudah didapat. Bahan yang digunakan adalah bambu sebagai tiang dan penyangga atap. Sebagai sekat keliling digunakan paranet (jaring), dengan atap menggunakan plastik ultra violet (UV). Sebagai dudukan instalasi hidroponik digunakan bambu yang dibelah (lihat Gambar 2). 


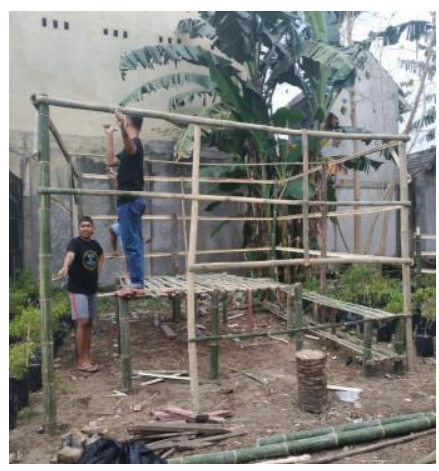

(a) Pemasangan rangka

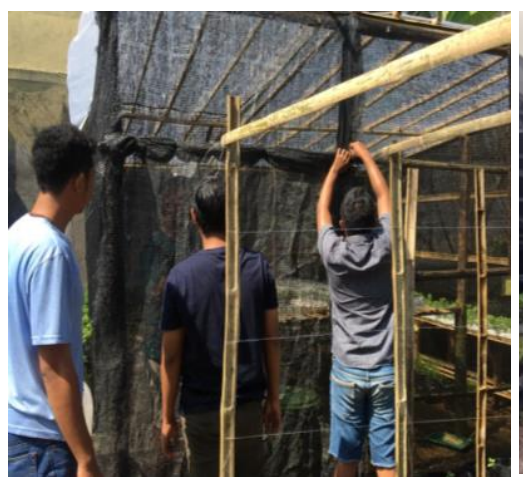

(b) Pemasangan paranet

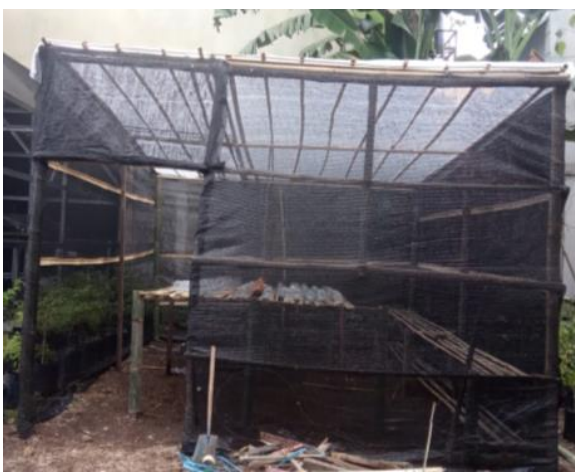

(c) Screen house siap digunakan

Gambar 2. Pembuatan screen house

(Sumber: Dokumentasi, 2021)

\section{Penyiapan media tanam}

Pada system hidroponik yang diaplikasikan, digunakan 2 media tanam yaitu digunakan adalah styrofoam dan botol bekas. Media hidroponik styrofoam menggunakan kotak kemasan makanan. Tujuannya adalah dapat memanfaatkan barang bekas yang masih bisa dipakai. Proses pembuatannya, styrofoam dilubangi bagian atasnya sebagai tempat gelas plastik (sebagai net pot) sebanyak 4 lubang sesuai ukurannya. Gelas plastik dilubangi secara acak sehingga air dapat masuk kedalam gelas plastik. Gelas plastik tersebut ditempatkan pada lubang yang telah disiapkan, dan siap digunakan. Styrofoam sebagai tempat nutrisi dan gelas untuk media tanam (lihat Gambar 3).
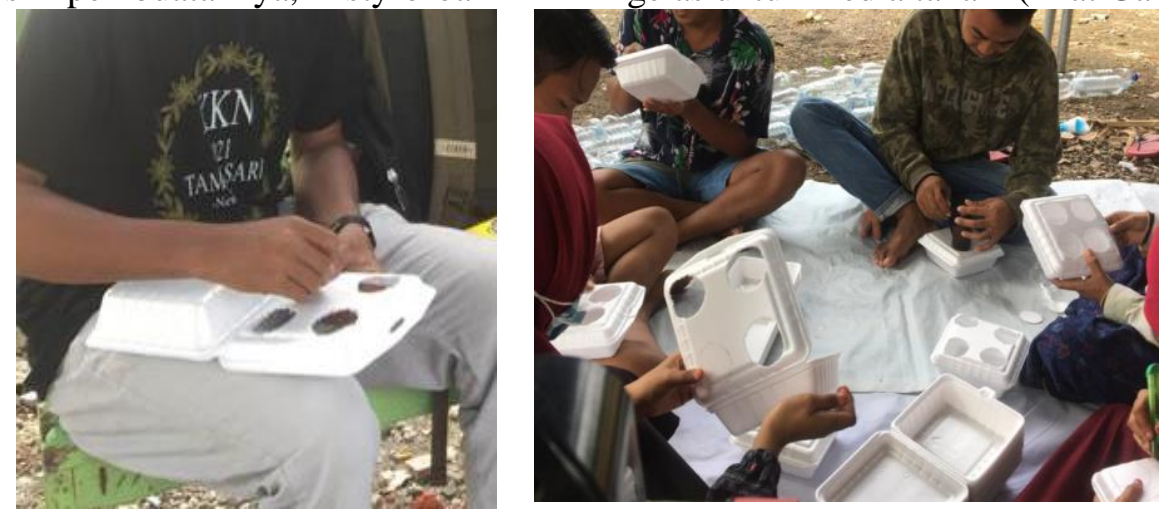

Gambar 3. Pembuatan media tanam Styrofoam

(Sumber: Dokumentasi, 2021)

Gambar 4 menunjukkan pembuatan media tanam hidroponik menggunakan beberapa buah botol plastik bekas kapasitas 1,5 liter. Diawali dengan melubangi botol plastik bekas menggunakan pipa besi atau kaleng sesuai dengan ukuran gelas plastik. Bagian belakang botol dilubangi untuk memasukkan bagian mulut botol pada bagian sambungan. Kemudian sambung botol-botol tersebut sehingga memanjang membentuk pipa, dengan cara menghubungkan mulut botol dan bagian belakang botol. Berikan lem untuk merekatkan botol satu dengan yang lain sehingga tidak mudah bocor dan lepas. 

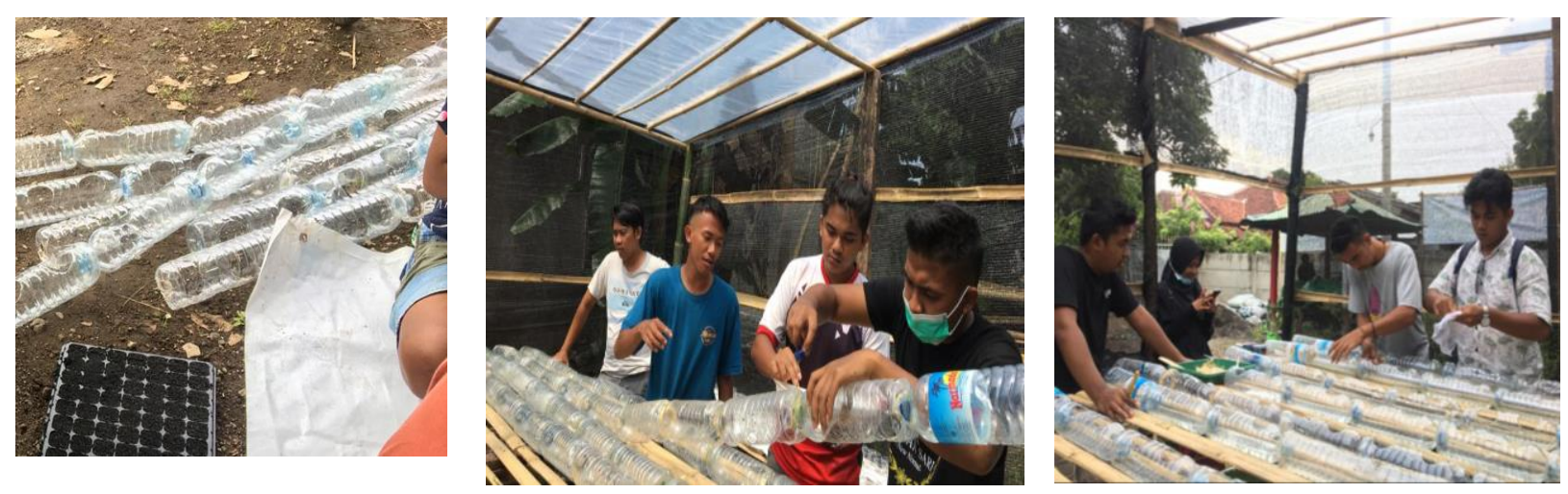

Gambar 4. Pembuatan media tanam botol bekas (Sumber: Dokumentasi, 2021)

\section{Proses pembibitan dan pemeliharaan tanaman}

Bersamaan dengan pembuatan media tanam, dilakukan pembibitan. Sehingga pada saat media sudah siap, maka bibit sudah siap dipindahkan atau ditanam pada media. Sebelumnya media harus diisi dengan larutan nutrisi. Gambar 5 menunjukkan kegiatan pembibitan dan penyiapan nutrisi tanaman dalam media tanam.
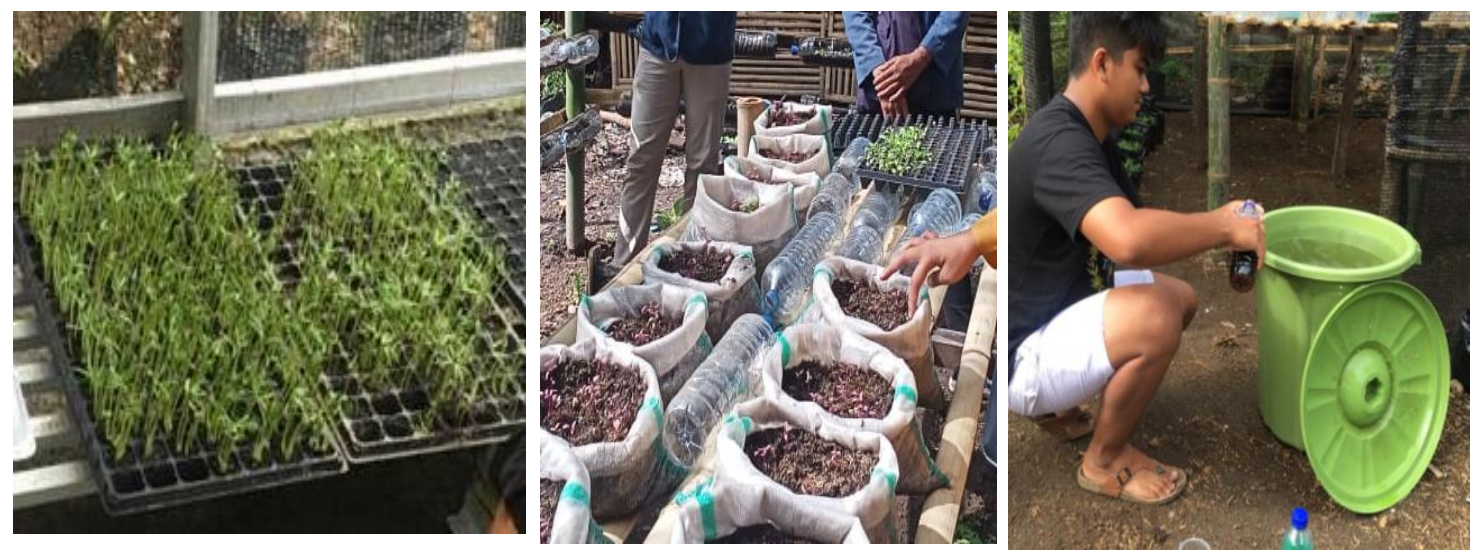

Gambar 5. Proses pembibitan tanaman dan penyiapan nutrisi (AB mix)

(Sumber: Dokumentasi, 2021)

Pemantauan pada masa pemeliharaan tanaman harus dilakukan secara rutin, terutama kontrol nutrisinya. Penambahan nutrisi dilakukan seminggu sekali. Hasil yang didapatkan pada media styrofoam untuk tanaman sawi dan selada setelah dilakukan pemeliharaan 40 hari mencapai panjang 30-40 cm. Sedangkan untuk yang menggunakan media botol bekas mencapai panjang 20-25 cm, seperti ditunjukkan pada Gambar 6. 


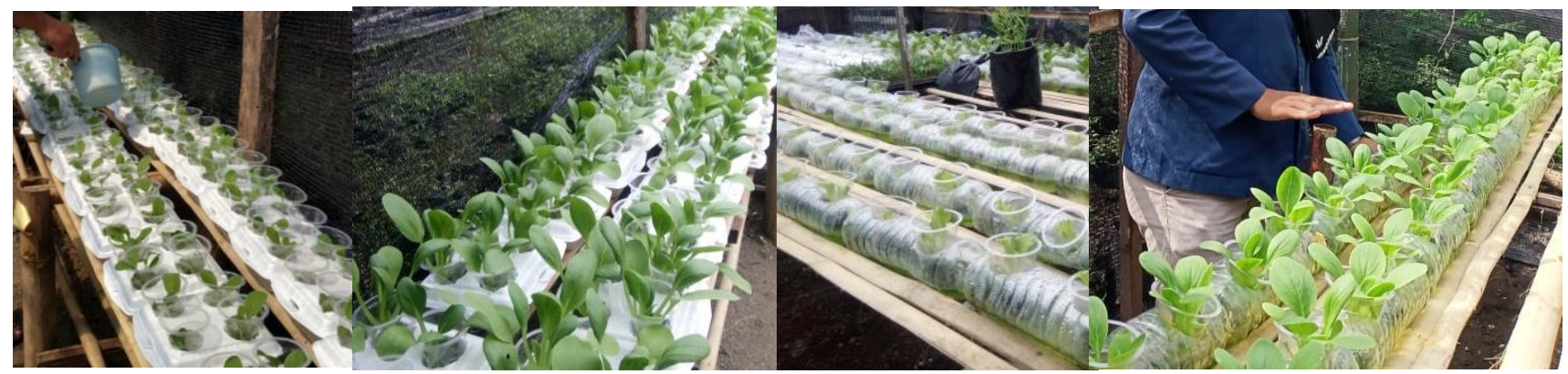

(a)

Gambar 6. Tahap pemeliharaan tanaman dengan media Styrofoam (a) dan botol bekas (b) (Sumber: Dokumentasi, 2021)

Pemanenan sudah dimulai pada hari ke 40 menjelang berakhirnya KKN. Hasil panen perdana sebagian dibagikan kepada masyarakat sekitar Lingkungan Seruni. Pada saat acara perpisahan dengan warga, sayur olahan dari hasil panen kebun percontohan ini, juga dihidangkan.

\section{Pendampingan dan pelatihan}

Selama pelaksanaan program sekaligus dilakukan pendampingan dengan cara memberikan pelatihan di kebun percontohan. Cara ini sangat efektif dalam meningkatkan
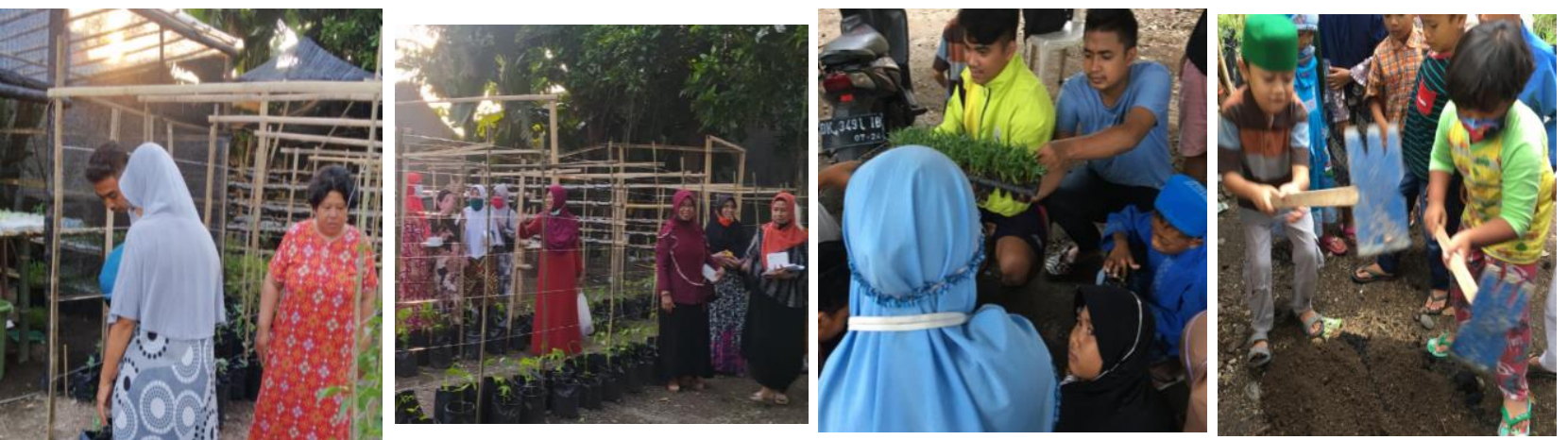

Gambar 7. Edukasi kepada kelompok tani dan anak-anak

(Sumber: Dokumentasi, 2021) keterampilan dan pemahaman berkebun yang berbeda dengan yang sebelumnya dilakukan. Dimana sebelumnya sudah biasa dengan sistem konvensional. Disamping kepada kelompok tani, dilakukan juga pengenalan metode hidroponik ini kepada anak-anak disekitar lokasi kebun percontohan. Hal ini merupakan salah satu usaha menanamkan minat dan menambah pengalaman anak-anak dalam berkebun dan mencintai lingkungan. Gambar 7 menunjukkan proses pendampingan dan pengenalan metode hidroponik kepada anak-anak. 


\section{Evaluasi pelaksanaan program}

Keunggulan metode penanaman system hidroponik adalah dapat menghemat lahan. Dari media yang digunakan, anaman yang ditanam pada media styrofoam pertumbuhannya lebih cepat dan hasilnya lebih baik dibandingkan yang menggunakan botol. Hal ini disebabkan media dengan styrofoam mampu menyedediakan nutrisi dengan baik. Sedangkan pada hidroponik yang menggunakan botol, nutrisi yang diberikan cepat habis akibat penguapan yang sangat cepat.

Fokus kegiatan sesuai karena lokasi mitra adalah perumahan dengan lahan terbatas, dan ibuibu yang mempunyai waktu luang untuk berkebun di pekarangan. Karena itu mitra sangat antusias, dan program berhasil diterapkan dengan indikator tanaman tumbuh sampai bisa dipanen. Dengan pembinaan yang kontinyu, peluang pengembangan kedepan cukup baik, dari skala konsumsi ke produksi.

\section{Luaran pelaksanaan program}

Luaran pelaksanaan program adalah publikasi pada jurnal pengabdian terakreditasi Sinta (segera disubmit), buku monograf (dalam proses editing) dan kebun contoh untuk kelompok tani Seruni Hijau, yang diharapkan dapat dikembangkan menjadi lebih produktif.

\section{Kesimpulan}

Program berhasil mengedukasi masyarakat bercocok tanam sayuran, dengan menggunakan sistem hidroponik. Indikasinya sayuran yang dikembangkan di kebun percontohan tumbuh subur hingga bisa dipanen dan dapat dinikmati. Melalui kebun edukasi (percontohan), masyarakat dapat memanfaatkan ruang kosong di pekarangan rumah untuk dijadikan tempat berkebun. Capaian ini keseriusan mahasiswa dalam memberikan bimbingan kepada masyarakat, serta antusiasme masyarakat (khususnya kolompok tani Seruni Hijau, serta dukungan seluruh pihak terkait.

\section{Ucapan Terima Kasih}

Terima kasih Kepada Lurah Taman Sari beserta perangkatnya, Ketua RT di Wilayah Lingkungan Seruni, warga masyarakat khususnya kelompok tani Seruni Hijau, atas dukungannya terhadap pelaksanaan program pengabdian ini, sehingga berjalan lancar sesuai rencana.

\section{Daftar Pustaka}

Badan Penelitian dan Pengembangan (Balitbang) Pertanian, Kementerian Pertanian. 2019. Kawasan Rumah Pangan Lestari - KRPL. https://www.litbang. pertanian.go.id/krpl/

Dinas Pertanian (Distan) Kota Sukabumi. 2015. Kelebihan dan Kekurangan Bercocok Tanam Hidroponik. https://distan. sukabumikota.go.id/kelebihan-dankekurangan-bercocok-tanam-hidroponik/

Hadiwardoyo, W., 2020. Kerugian Ekonomi Nasional Akibat Pandemi Covid19. Baskara: Journal of Business and Entrepreneurship, 2(2) : 83-92. https://jurnal.umj.ac.id/index.php/ baskara/ article/view/6207

Lembaga Penelitian dan Pengabdian Masyarakat (LPPM), Universitas Mataram. 2020. Panduan Kuliah Kerja Nyata (KKN) Era New Normal Universitas Mataram.

Mulasari, S. A. 2018. Penerapan Teknologi Tepat Guna (Penanam Hidroponik Menggunakan Media Tanam) Bagi Masyarakat Sosrowijayan Yogyakarta. Jurnal Pemberdayaan: Publikasi Hasil Pengabdian kepada Masyarakat, 2 (3) : 425-430. ISSN: 2580-2569.

Pejabat Pengelola Informasi dan Dokumentasi (PPID). 2020. Profil Kelurahan Taman Sari. $\quad$ http://www.sipppid.mataramkota.go.id/file/profilkelurahan-taman-sari

Rijali, 2018. Analisis Data Kualitatif. Jurnal Alhadharah. 17 (23). https://www.resear chgate.net/ publication/331094976 ANALISIS_DATA_KUALITATIF/link/5c 657021a6fdccb608c289e8/download

Suara NTB. 2020. Alih Fungsi Lahan di Mataram Meningkat. https://www.suara ntb.com/alih-fungsi-lahan-di-matarammeningkat 